\title{
GLUCAGON-LIKE PEPTIDE-1 AFFECTS TASTE PERCEPTION DIFFERENTLY IN WOMEN: A RANDOMIZED, PLACEBO-CONTROLLED CROSSOVER STUDY
}

\author{
Maja Baretić1,5, Vesna Kušec ${ }^{2,5}$, Valentina Uroić3 ${ }^{3}$ Ivana Pavlić-Renar ${ }^{1,5}$ and Velimir Altabas $s^{4,5}$ \\ ${ }^{1}$ Division of Endocrinology, Department of Internal Medicine, Zagreb University Hospital Centre, Zagreb, Croatia; \\ ${ }^{2}$ Clinical Institute of Laboratory Diagnosis, Zagreb University Hospital Centre, Zagreb, Croatia; \\ ${ }^{3}$ Department of Nutrition and Dietetics, Zagreb University Hospital Centre, Zagreb, Croatia; \\ ${ }^{4}$ Department of Endocrinology, Diabetes and Metabolic Diseases, Sestre milosrdnice University Hospital Centre, \\ Zagreb, Croatia; ${ }^{5}$ School of Medicine, University of Zagreb, Zagreb, Croatia
}

\begin{abstract}
SUMMARY - Gastrointestinal tract is an important connector between food intake and body weight, it senses basic tastes in a similar manner as the tongue. The aim of the study was to find out how gut hormone glucagon-like peptide-1 (GLP-1) influences taste preference. Fourteen healthy participants (six male and eight female) were included in this double-blind, placebo-controlled crossover study. After overnight fast and salty fluid (oral sodium load), participants were randomized to receive placebo $(500 \mathrm{~mL}$ of $0.9 \%$ saline $)$ or GLP-1 infusion $(1.5 \mathrm{pmol} / \mathrm{kg} / \mathrm{min})$ over a 3 -hour period. At the end of infusion, participants chose food preferences from illustrations of food types representing 5 tastes. After 7 days, the protocol was repeated, this time those that had received placebo first got GLP-1 infusion, and those having received GLP-1 first got placebo. Change of taste preference after GLP-1 infusion but not after placebo was reported as response, and non-response was reported in case of taste persistence. A statistically significant difference in response type was found between genders, with women being more likely to change their taste preference after GLP-1 than men. The change of taste upon GLP-1 infusion observed in women might be ascribed to estrogen weight-lowering effects accomplished by receptor-mediated delivery.
\end{abstract}

Key words: Glucagon-like peptide 1; Taste; Food preferences; Cross-over studies; Double-blind method

\section{Introduction}

Incretins are substances secreted in the gut after a meal. The incretin hormone glucagon-like peptide-1 (GLP-1) is released from intestinal enteroendocrine $\mathrm{L}$ cells in response to a carbohydrate meal. GLP-1 has many levels of action, but currently it is primarily known for its effect on beta cells (the peptide lowers

Correspondence to: Maja Baretic, $M D, P h D$, Division of Endocrinology, Department of Internal Medicine, Zagreb University Hospital Centre, School of medicine, University of Zagreb, Kišpatićeva 12, HR-10000 Zagreb, Croatia

E-mail: mbaretic@kbc-zagreb.hr

Received May 8, 2018, accepted June 1, 2018 blood sugar by stimulating insulin secretion, which augments pancreas response within a safe glycemic range without inducing hypoglycemia). GLP-1 reduces gastric emptying, lowers appetite by promoting satiety via hypothalamic receptors and reduces food intake. As a consequence, GLP-1 action promotes weight loss ${ }^{1}$. GLP-1 receptor agonists are injectable hypoglycemic agents, they regulate glucose level and promote weight loss. One of these agents, liraglutide, is currently indicated at a higher dosage for the treatment of obesity ${ }^{2}$.

Few clinical studies have demonstrated the important association of GLP-1 and different food preferences in humans. In patients with diabetes type 2, 
GLP-1 had an effect on appetite via enhanced satiety and reduced energy intake ${ }^{3}$. Intravenous infusions of GLP-1 decreased spontaneous food intake in healthy non-obese males ${ }^{4}$. In addition, the process of chewing can increase satiety and reduce the decrease in GLP-1 concentration $^{5}$, and a relationship was found between various styles of mastication and GLP-1 secretion ${ }^{6}$. Data on the effects of GLP-1 on taste preference are not available.

To date, there is no specific group of patients identified as GLP-1 receptor agonist 'responders' or 'nonresponders' with respect to weight loss. Some patients report a diminished craving for food and/or a change in food preference with GLP-1 therapy. The hypothesis is that there are some predictors in a group of healthy normal weight people that could explain responsiveness to infusion of native GLP-1 regarding different food preference. The aim of this study was to investigate whether GLP-1 may influence taste preference and cause changes in some metabolic parameters.

\section{Subjects and Methods}

The study was conducted at the Division of Endocrinology, Department of Internal Medicine, Zagreb University Hospital Centre. It was approved by the Ethics Committee of the Zagreb University Hospital Centre and registered at ClinicalTrials.gov Identifier: NCT02130778.

Fourteen healthy non obese (body mass index $(\mathrm{BMI})<30)$ participants (six male and eight female, mean age 37.4 years, range 29-64) were randomized for a mechanism based driven, double-blind, placebocontrolled crossover study. The participants were randomized from the group of healthy volunteers. One participant was excluded post-randomization (Fig. 1).

Insulin sensitivity was estimated by simultaneously measured fasting plasma glucose (mean fasting glucose $4.4 \mathrm{mmol} / \mathrm{L}$, range 3.8-5.1) and fasting plasma insulin (mean fasting insulin $6.9 \mathrm{mU} / \mathrm{L}$, range 3.3-17) using the Homeostasis Model Assessment (HOMA) Calculator (University of Oxford 2013) ${ }^{7}$. Assessment included HOMA insulin resistance (IR) (mean HOMA IR 0.84, range 0.41-2.12), beta cell function HOMA2B (mean \%B 112.1, range 84.1-191) and insulin sensitivity HOMA2S (mean \%S 119.95, range 47.1-246.2). Baseline GLP-1 was measured in fasting state (mean $13.27 \mathrm{pmol} / \mathrm{L}$, range 0-17). Body composition was estimated using bioelectrical impedance analysis (mean fat percentage 19.9\%, range 14-32; mean fat mass $15.3 \mathrm{~kg}$, range 7.9-20.1; mean muscle mass $20.16 \mathrm{~kg}$, range $38.1-77.4$; and mean visceral fat rating (VFR) 3.92, range 1-7).

Bioimpedance assessment was performed using body composition analyzer model TANITA SC-330 (Tanita Europe B:V: 2004). The BMI of study subjects was between 18 and $28 \mathrm{~kg} / \mathrm{m}^{2}$. Subjects with BMI $>25 \mathrm{~kg} / \mathrm{m}^{2}$ met the inclusion criterion of normal fat percentage; the mean BMI was $23.15 \mathrm{~kg} / \mathrm{m}^{2}$ (range 18.1- 28.4).

Synthetic human GLP-1 was obtained from Bachem (Bubendorf, Switzerland). The peptide content was used in a calculated dosage dissolved in $0.9 \%$ saline solution. Placebo was $0.9 \%$ saline solution. The soup used in the trial served as an oral sodium load, and its volume was $0.5 \mathrm{~L}$ with $12 \mathrm{~g} \mathrm{NaCl}$ (mean daily salt intake in Croatia). The nutrient content of the ingested soup included virtually no fat, proteins or sugar, with only a small amount of flavor enhancer (monosodium glutamate) and artificial food coloring. The soup concentrate was dissolved in standard bottled water. The same bottled water brand (natural artesian water, calcium/magnesium ratio $2: 1, \mathrm{pH} 7.4$ ) was served as a drink after the soup.

Food map was designed by a registered dietitian. The map consists of five pictures. Each picture is a selection of food representing one particular taste (sweet, sour, salty, bitter and umami). The selected food has one dominant, easily recognizable taste.

Blood for GLP-1 assessment was drawn through the antecubital cannula into syringes with EDTA (6 $\mathrm{mol} / \mathrm{L})$ and aprotinin (1000 kIU/L) and kept on ice. After centrifugation, plasma samples were kept frozen at $-20{ }^{\circ} \mathrm{C}$ until analysis. GLP- 1 was determined by the Active GLP-1 (7-36) ELISA ALPCO diagnostic kit.

Standard laboratory methods were used for measurement of laboratory parameters.

\section{Statistical analysis}

Data were analyzed using SPSS software (IBM SPSS Statistics for Windows, Version 24.0. Armonk, NY: IBM Corp.). Descriptive statistics was used to describe the basic features of the study sample. Since Kolmogorov-Smirnov test for normality of distribution showed some variables deviating significantly 


\section{Flow Diagram}

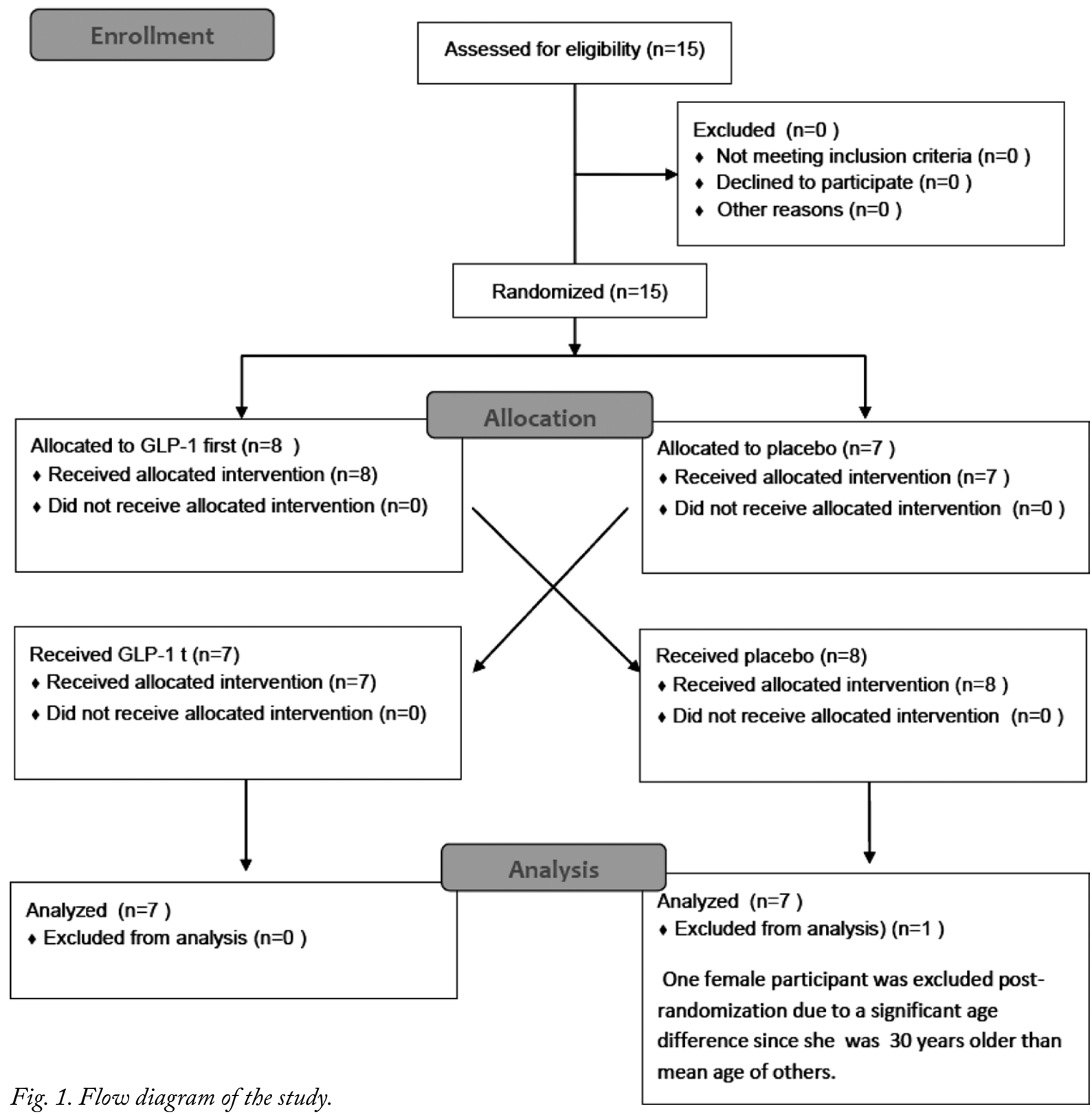

from normal distribution, non-parametric indicators were also shown as descriptive data. So, for continuous variables, mean \pm standard deviation, and median and interquartile range were used to describe initial data. Binary or categorical outcome variables were analyzed using $\chi^{2}$-test for comparison of genders in the two groups: $2 \times 5$ contingency $\chi^{2}$ was used for comparison of the choice of food after placebo or GLP-1 infusion, and $2 \times 2$ contingency $\chi^{2}$ was used for comparison of genders according to response to placebo or GLP-1 infusion. Independent samples t-test was used to compare responders and non-responders according to laboratory and body composition parameters (body fat percentage). Since Levene's test showed a statistically significant difference suggesting that variances were not homogeneous for some variables, we used the $\mathrm{t}$ test level of significance when 'equal variances were not assumed' to compensate for the lack of homogeneity. Two-way repeated measures ANOVA was used to determine whether the level of insulin changed across 
the 3 measurement points (baseline, at $3 \mathrm{~h}$ and at $6 \mathrm{~h}$ of starting infusion), using Bonferroni correction for multiple comparisons. A significance level of 5\% was used throughout the analysis. Sample size was not calculated prior to the study. Rather, it was limited due to expenses of the study protocol, testing procedures and availability of participants since repeated measures were required to obtain necessary data. Also, the sample size corresponded to previous studies performed with a similar protocol, which included 12-16 participants $^{3,4}$. Post-hoc power analysis using free software GPower 3.1 showed very low power of analysis, given the sample size $n=14$, alpha error of probability 0.05 , and two-way statistical significance (post hoc power 0.20 for $\chi^{2}$-tests, 0.15 for independent samples t-tests, and 0.19 for repeated measures ANOVA) ${ }^{7}$.

\section{Study protocol}

Before being enrolled in the study (screening), the participants completed a medical history interview. Female participants were not menopausal women; they all had regular menstrual cycles and proper methods of contraception (median age of female participants was 33 years, range 30-45). None of the participants reported food neophobia and/or 'picky/fussy' eating, either currently or in childhood. All participants had normal glycemia; diabetes was excluded based on the standard glucose tolerance test, according to the American Diabetes Association guidelines ${ }^{8}$. There were no smokers and currently had no chronic diseases. They were instructed to come next day fasting for the first visit (Fig. 1).

Randomization was performed by a co-worker not included in the study. Eight subjects were randomized to receive infusion with GLP-1 first and then placebo; another seven subjects were randomized to receive placebo first and then infusion with GLP-1.

At the first visit, participants signed their informed consent. Blood was drawn for laboratory analysis and routine physical examination and bioimpedance assessment was performed.

On the second visit day, participants arrived to the research unit in the morning after overnight fast. Initially, oral saline load was delivered in the form of a standardized meal (soup). The soup was consumed in 30 minutes; a sodium-containing meal was used because it might improve the overall flavor. Participants were instructed to drink $1 / 2 \mathrm{~L}$ of bottled water during the next 1 hour. In addition to the soup and water, saline infusion with or without GLP-1 (1.5 pmol/kg/ min) was administered at a rate of $0.06 \mathrm{~mL} / \mathrm{kg} / \mathrm{min}$ over $3 \mathrm{~h}$ from the beginning of oral sodium load. The investigators and nurses performing the procedure were blinded to the test conditions; the solutions were prepared by a technician not involved with study participants. Blood samples were obtained at $180 \mathrm{~min}$ and $360 \mathrm{~min}$ from the beginning of infusion. At the end of the infusion, illustrations of food types were presented and the participants were instructed to select the most desirable food item. They were instructed to return after at least 7 days for a third visit, fasting as before. The same procedure as on visit 2 was performed on visit 3 ; in one visit they received saline infusion with and in another without GLP-1 (1.5 pmol $/ \mathrm{kg} / \mathrm{min})$.

\section{Results}

All 15 participants underwent the same protocol as described; one participant randomized to receive infusion with GLP-1 first was excluded due to significant age difference, in order to retain group homogeneity according to age. This female subject was more than 30 years older than mean age of others included in the study and was excluded due to the fact that taste buds diminish as people get older, resulting in declining gustatory function, although age was not an exclusion criterion.

Seven of the 14 subjects analyzed gave different answers to the question: "What would you like most to eat right now" after placebo (saline) infusion and after GLP-1 infusion. These subjects were considered responders (with change of taste preference). Among responders, the most common taste preference following placebo was sweet ( 3 of 7 responders). Following GLP-1 infusion, sweet was again the most prevalent taste (3 of 7 responders), although present in those participants who had another taste preference following placebo. There was no statistically significant difference between specific taste preference following placebo and GLP-1 infusion. In the responder group, four subjects received GLP-1 infusion first and three subjects received placebo first, suggesting that this order of infusion made no difference. Seven of them gave identical answers to the same question after placebo or GLP-1 infusion; these participants were considered non-responders (without change of taste). Table 1 


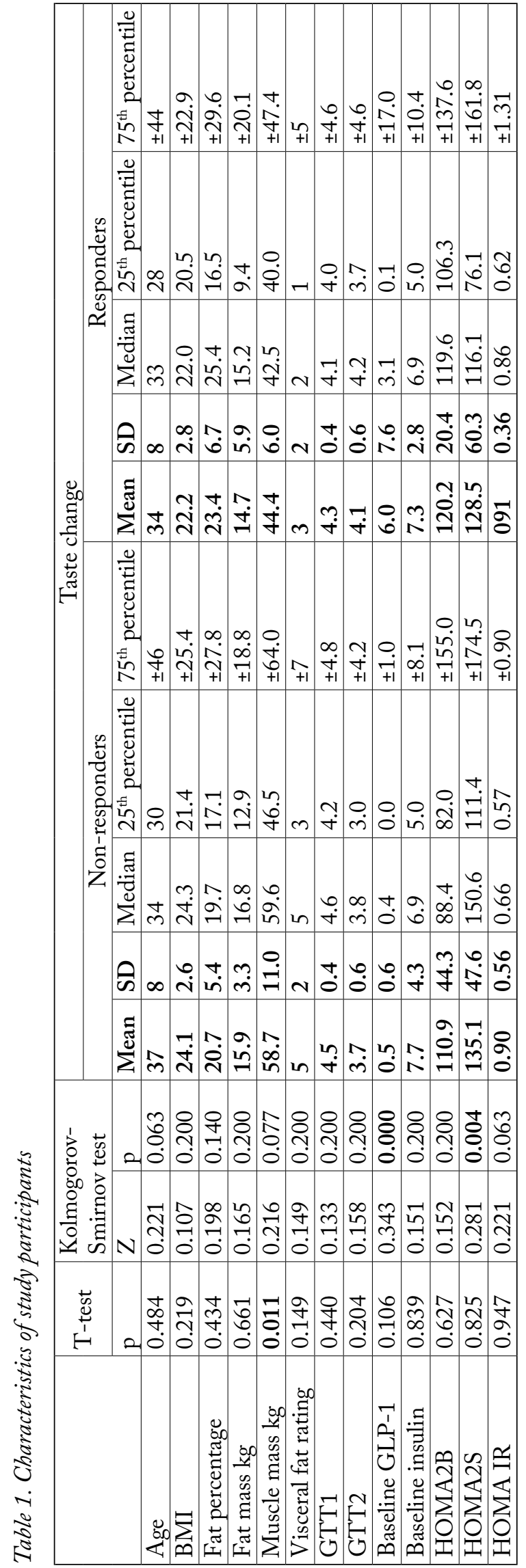

shows characteristics of these two groups. An analysis was conducted to compare age, BMI, fat percentage, fat and muscle mass, VFR, fasting glucose and glucose after 2-hour glucose tolerance test, baseline insulin, baseline GLP-1, HOMAB\%, HOMA IR and HOMA $2 S$ between the two groups. There were no statistically significant differences between the groups of responders and non-responders in the above measures ( $p>0.05$ all), except for initial muscle mass, which was significantly higher in non-responders than in responders.

The groups were homogeneous with respect to age, anthropometric parameters and baseline metabolic laboratory values. The responder group included six females and one male. The non-responder group included five males and two females. A $2 \times 2$ contingency $\chi^{2}$ table was used for gender comparison in the two groups, i.e. yes/no response to placebo/GLP-1 in males and females. The $\chi^{2}$-test showed a statistically significant gender difference $\left(\chi^{2}=4.667, \mathrm{df}=1, \mathrm{p}=0.031\right)$; women were more likely to change their taste preference after GLP-1 infusion than men.

To compare food preference after placebo in the groups of responders and non-responders (i.e. selection of one of five tastes and yes/no response to placebo/vehicle), a $2 \times 5 \chi^{2}$ table was used. The preference for some specific tastes after oral and i.v. sodium loads did not differ between responders and non-responders $\left(\chi^{2}=3.333, d f=4, p=0.504\right)$. Before GLP-1 infusion, no preference for a specific taste existed.

There was no statistically significant difference at the $5 \%$ level $(\mathrm{t}=-1.900, \mathrm{df}=6.100, \mathrm{p}=0.106)$ in GLP-1 baseline values between responders and non-responders. Two-way repeated measures ANOVA was used to determine whether the level of insulin changed across the 3 measurement points (baseline, after $3 \mathrm{~h}$ and $6 \mathrm{~h}$ of the beginning of infusion). The difference between the groups was not statistically significant at the level of $5 \%\left(\mathrm{~F}_{(1,12)}=0.155, \mathrm{p}>0.05\right)$, as so was not the interaction between the groups and the time elapsed from infusion $\left(\mathrm{F}_{(1.1,13.6)}=0.734, \mathrm{p}=0.423\right)$. The same analysis for GLP-1 levels showed that GLP-1 levels were not significantly influenced by the time elapsed from infusion $\left(\mathrm{F}_{(1.1,13.6)}=0.500, \mathrm{p}=0.518\right)$, without difference between the groups $\left(\mathrm{F}_{(1,12)}=3.566, \mathrm{p}=0.083\right)$, and the interaction between the groups and the time elapsed from infusion $\left(\mathrm{F}_{(1.1,13.6)}=2.618, \mathrm{p}=0.125\right)$. 


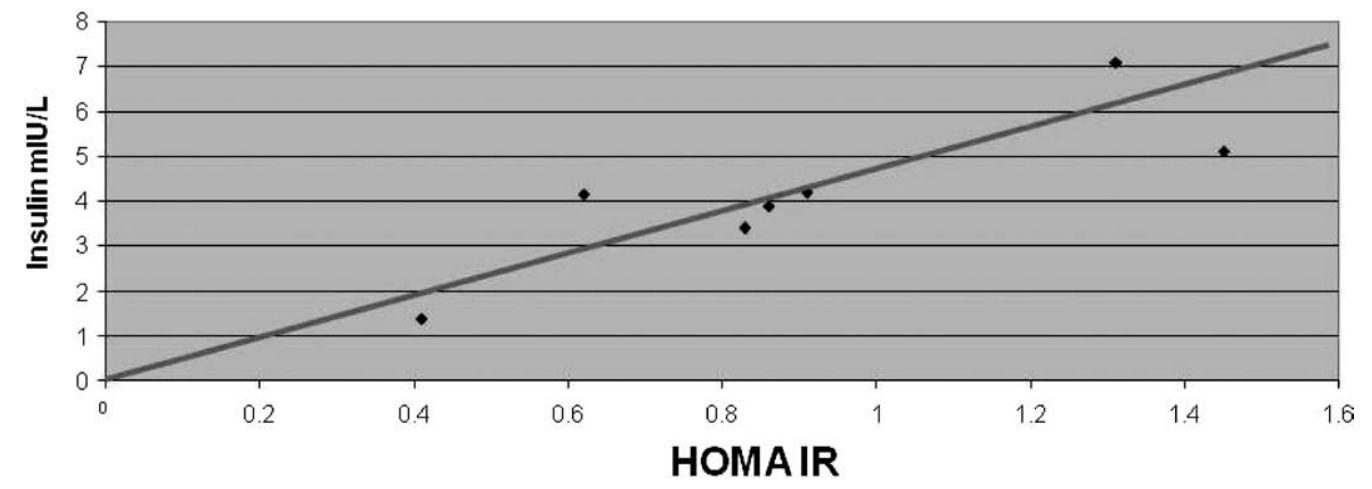

Fig. 2. Correlation between insulin resistance (HOMA IR) and insulin level $3 \mathrm{~h}$ after glucagon-like peptide-1 (GLP-1) infusion in the responder group.

There was a positive correlation in responders between the body composition parameter (body fat mass in $\mathrm{kg}$ ) and insulin level $3 \mathrm{~h}$ after GLP-1 infusion. Spearman's rank correlation coefficient was $\mathrm{r}=0.710$ $(p<0.010)$. The higher the body fat mass, the higher was insulin response to GLP infusion. We also found a strong positive correlation between insulin resistance (HOMA IR) and insulin level at $3 \mathrm{~h}$ after GLP-1 infusion in responders, $r=0.89$ ( $p<0.010)$ (Fig. 2). The higher insulin resistance in responders indicated higher insulin response to GLP infusion. A negative correlation was demonstrated for insulin sensitivity (HOMA2S) and insulin level $\mathrm{r}=-0.89$ ( $\mathrm{p}<0.010)$. In non-responders, there was no correlation between HOMA IR and insulin level at $3 \mathrm{~h}(\mathrm{r}=-0.180)$.

\section{Discussion}

We confirmed the initial hypothesis concerning predictors that could explain responsiveness to native GLP-1 infusion regarding different food preference. The results of this study suggested that women were more likely to change their taste preference after GLP-1 infusion than men. Why are women more prone to taste change after GLP-1 infusion than men?

Difference in sensitivity to central leptin and insulin in male and female rats and the influence of gonadal hormones on their central action is well documented $^{10}$. Estrogens play an important role in the regulation of energy homeostasis. The weight-lowering effects of estrogens are associated with decreased food intake and increased energy expenditure in experimental animals, modulating energy expenditure and feeding behavior through leptin-like effects in the hypothalamus ${ }^{11}$. Estrogens act directly on brain serotonin (5-HT) neurons ${ }^{12}$. Deletion of the gene encoding estrogen receptor $\alpha$ from the entire brain results in obesity due to both hyperphagia and decreased energy expenditure ${ }^{13}$. Estrogen receptors are expressed in large quantities in the dorsal raphe nuclei, where most 5-HT neurons are located ${ }^{14}$. There is a relationship between eating disorders and estrogen. Some theories claim that estrogens directly act through dorsal raphe nuclei 5-HT neurons to inhibit binge eating and that impaired brain 5-HT signaling is an important component of binge eating development ${ }^{15-18}$. In humans, weight gain during menopause is associated with estrogen decline, and such obesity is independent of aging $^{19}$. The absence of estrogens has a significant effect on obesity in menopausal women ${ }^{20,21}$. Epidemiologically, women are approximately three-fold more vulnerable than men to psychiatric eating disorders ${ }^{22}$. Estrogens could be a therapeutic option for obesity and type 2 diabetes ${ }^{23}$, but their usage is limited due to their female-specific gynecologic action and tumor-promoting properties. There is a potential to develop selective estrogen receptor modulators through tissuespecific actions. Until now, such a substance was not easy to develop due to remaining toxicity concerns and mechanistic uncertainties ${ }^{24}$.

Another option for estrogen delivery is based on a peptide carrier that selectively delivers estrogens to specific tissues. Improved estrogen action is accomplished by GLP-1 receptor-mediated delivery. Central stimulation of the GLP-1 receptors reduces feeding and food-reward behavior, and this action could be 
important for the anorexic actions of estrogens. In experimental studies, GLP-1-based estrogen conjugates were more effective in reducing adiposity and improving hyperglycemia and dyslipidemia in metabolically compromised obese mice than individual agonists alone, independent of $\operatorname{sex}^{25}$. In one experimental study, the estrogen antagonist was administered centrally with GLP-1 receptor agonist exendine 4 to fasting male and female rats, and different sensitivities to the food reward were noted between female and male rats. Female rats exhibited a significant reduction in active lever presses and sucrose rewards earned in the nonfood deprived state after exendine 4 treatment. Stimulation with synthetic GLP-1R agonist confirmed different food-motivated behaviors in female rats and their interaction with central estrogen signaling ${ }^{26}$. Such data indicate an increased sensitivity to GLP-1 in females.

Our study results are consistent with previously mentioned experimental findings pointing to the fact that gender difference in the physiology of eating exists $^{27}$. Both groups (responders and non-responders) were initially homogeneous, with the exception of initial muscle mass, which was significantly higher in non-responders. This observation could be explained by the fact that the non-responder group primarily consisted of $\operatorname{men}^{27}$. Both groups were optimally hydrated to prevent hunger and thirst responses from being mistaken for each other.

Exclusively analyzing the responders, a positive correlation was noted between body fat percentage and insulin level after GLP-1 infusion; a higher body fat percentage was associated with higher insulin response to GLP-1 infusion. The same correlation was confirmed for the VFR, i.e. higher VFR was associated with increased insulin response to GLP-1 infusion. The strongest positive correlation in responders was between insulin resistance HOMA IR and insulin level after GLP-1 infusion. Such a correlation was not confirmed in the non-responder group. As expected, in the responder group, body fat percentage was positively correlated with insulin resistance. Although no statistically significant difference in baseline GLP-1 level was noted between responders and non-responders, it seems that the responders with more symptoms of metabolic syndrome (total fat, visceral fat and insulin resistance) react with higher insulin after GLP-1 infusion.
To our knowledge, this is the first study exploring sex differences in response to GLP-1 infusion. A study limitation was the number of participants (although similar studies assessing GLP-1 involved 15-16 participants). The sample size did not exclude inter- and intra-individual variability.

In conclusion, we found healthy non-obese females to respond differently to GLP-1 infusion than males. Females had a tendency to change their taste preferences following increase in GLP-1 plasma levels. The observed results may be attributable to the effect of estrogen in females and the improved central action accomplished by GLP-1 receptor-mediated delivery. Sex differences in the physiology of eating and response to GLP-1 stimuli may contribute to better understanding of human obesity and eating disorders.

\section{Acknowledgment}

The study was supported by Merck Sharp \& Dohme Corp.

\section{References}

1. Baretić M, Troskot R. How to fight obesity with antidiabetic drugs: targeting gut or kidney? Minerva Endocrinol. 2015 Mar;40(1):71-83.

2. Garber A, Henry RR, Ratner R, Hale P, Chang CT, Bode B; LEAD-3 (Mono) Study Group. Liraglutide, a once-daily human glucagon-like peptide 1 analogue, provides sustained improvements in glycaemic control and weight for 2 years as monotherapy compared with glimepiride in patients with type 2 diabetes. Diabetes Obes Metab. 2011 Apr;13(4):348-56. doi: 10.1111/j.1463-1326.2010.01356.x.

3. Gutzwiller JP, Drewe J, Göke B, Schmidt H, Rohrer B, Lareida $\mathrm{J}$, et al. Glucagon-like peptide- 1 promotes satiety and reduces food intake in patients with diabetes mellitus type 2 . Am J Physiol. 1999 May;276(5 Pt 2):R1541-4. doi: 10.1152/ ajpregu.1999.276.5.R1541.

4. Gutzwiller JP, Göke B, Drewe J, Hildebrand P, Ketterer S, Handschin $\mathrm{D}$, et al. Glucagon-like peptide-1: a potent regulator of food intake in humans. Gut. 1999 Jan;44(1):81-6.

5. Xu J, Xiao X, Li Y, Zheng J, Li W, Zhang Q, Wang Z. The effect of gum chewing on blood GLP-1 concentration in fasted, healthy, non-obese men. Endocrine. 2015 Sep;50(1):93-8. doi: 10.1007/s12020-015-0566-1

6. Sonoki K, Iwase M, Takata Y, Nakamoto T, Masaki C, Hosokawa $\mathrm{R}$, et al. Effects of thirty-times chewing per bite on secretion of glucagon-like peptide- 1 in healthy volunteers and type 2 diabetic patients. Endocr J. 2013;60(3):311-9.

7. HOMA Calculator@ The University of Oxford 2013 [cited 2017 Aug):[about 1 p]. (cited 2017 May 8). Available from: https://www.homacalculator/download.php 
8. Faul F, Erdfelder E, Lang AG, Buchner A. G*Power 3: a flexible statistical power analysis program for the social, behavioral, and biomedical sciences. Behav Res Methods. 2007 May;39 (2):175-91.

9. Summary of Revisions: Standards of Medical Care in Diabetes-2018. Diabetes Care. 2018 Jan;41(Suppl 1):S4-S6. doi: 10.2337/dc18-Srev01

10. Clegg DJ, Brown LM, Woods SC, Benoit SC. Gonadal hormones determine sensitivity to central leptin and insulin. Diabetes. 2006 Apr;55(4):978-87.

11. Brown LM, Clegg DJ. Central effects of estradiol in the regulation of food intake, body weight, and adiposity. J Steroid Biochem Mol Biol. 2010 Oct;122(1-3):65-73. doi: 10.1016/j. jsbmb.2009.12.005

12. Gao Q, Mezei G, Nie Y, Rao Y, Choi CS, Bechmann I, et al. Anorectic estrogen mimics leptin's effect on the rewiring of melanocortin cells and Stat3 signaling in obese animals. Nat Med. 2007 Jan;13(1):89-94.

13. Merchenthaler I, Lane MV, Numan S, Dellovade TL. Distribution of estrogen receptor alpha and beta in the mouse central nervous system: in vivo autoradiographic and immunocytochemical analyses. J Comp Neurol. 2004 May 24;473(2): 270-91.

14. Xu Y, Nedungadi TP, Zhu L, Sobhani N, Irani BG, Davis KE, et al. Distinct hypothalamic neurons mediate estrogenic effects on energy homeostasis and reproduction. Cell Metab. 2011 Oct 5;14(4):453-65. doi: 10.1016/j.cmet.2019.04.006.

15. Dalmasso C, Amigone JL, Vivas L. Serotonergic system involvement in the inhibitory action of estrogen on induced sodium appetite in female rats. Physiol Behav. 2011 Sep 1; 104(3):398-407. doi: 10.1016/j.physbeh.2011.04.029

16. Jimerson DC, Lesem MD, Kaye WH, Hegg AP, Brewerton TD. Eating disorders and depression: is there a serotonin connection? Biol Psychiatry. 1990 Sep 1;28(5):443-54.

17. Steiger H. Eating disorders and the serotonin connection: state, trait and developmental effects. J Psychiatry Neurosci. 2004 Jan;29(1):20-9.
18. Luo X, Donnellan MB, Burt SA, Klump KL. The dimensional nature of eating pathology: evidence from a direct comparison of categorical, dimensional, and hybrid models. J Abnorm Psychol. 2016 Jul;125(5):715-26. doi: 10.1037/abn0000174

19. Villaverde Gutiérrez C, Ramírez Rodrigo J, Olmedo Alguacil MM, Sánchez Caravaca MA, Argente del Castillo Lechuga $\mathrm{MJ}$, et al. Overweight obesity and cardiovascular risk in menopausal transition. Nutr Hosp. 2015 Oct 1;32(4):1603-8. doi: 10.3305/nh.2015.32.4.9380.

20. Lizcano F, Guzmán G. Estrogen deficiency and the origin of obesity during menopause. Biomed Res Int. 2014;2014:757461. doi: 10.1155/2014/757461

21. Vranešić-Bender D. The role of nutraceuticals in anti-aging medicine. Acta Clin Croat. 2010 Dec;49(4):537-44.

22. Swanson SA, Crow SJ, Le Grange D, Swendsen J, Merikangas KR. Prevalence and correlates of eating disorders in adolescents. Results from the national comorbidity survey replication adolescent supplement. Arch Gen Psychiatry. 2011 Jul;68(7): 714-23. doi: 10.1001/archgenpsychiatry

23. Mauvais-Jarvis F. Estrogen and androgen receptors: regulators of fuel homeostasis and emerging targets for diabetes and obesity. Trends Endocrinol Metab. 2011 an;22(1):24-33. doi: 10.1016/j.tem.2010.10.002

24. Nilsson S, Koehler KF, Gustafsson JÅ. Development of subtype-selective oestrogen receptor-based therapeutics. Nat Rev Drug Discov. 2011 Sep 16;10(10):778-92. doi: 10.1038/ $\operatorname{nrd} 3551$.

25. Finan B, Yang B, Ottaway N, Stemmer K, Müller TD, Yi CX, et al. Targeted estrogen delivery reverses the metabolic syndrome. Nat Med. 2012 Dec;18(12):1847-56. doi: 10.1038/ nm.3009.

26. Richard JE, Anderberg RH, López-Ferreras L, Olandersson K, Skibicka KP. Sex and estrogens alter the action of glucagonlike peptide-1 on reward. Biol Sex Differ. 2016 Jan 16;7:6. doi: 10.1186/s13293-016-0059-9.

27. Asarian L, Geary N. Sex differences in the physiology of eating. Am J Physiol Regul Integr Comp Physiol. 2013 Dec;305 (11):R1215-67. doi: 10.1152/ajpregu.00446.2012 


\section{Sažetak \\ GLUKAGONU SLIČAN PEPTID-1 RAZLIČITO UTJEČE NA PERCEPCIJU OKUSA U ŽENA: RANDOMIZIRANA, PLACEBOM KONTROLIRANA UKRIŽENA STUDIJA}

\section{Baretić, V. Kušec, V. Uroić, I. Pavlic-Renar i V. Altabas}

Probavni sustav povezuje unos hrane i tjelesnu masu razlikujući osnovne okuse sličnim mehanizmima kao i jezik. Cilj ove studije bio je istražiti kako glukagonu sličan peptid-1 (GLP-1) utječe na sklonost određenom okusu. Četrnaestoro zdravih ispitanika (šest muškaraca i osam žena) uključeno je u randomiziranu, placebom kontroliranu ukriženu studiju. Ispitanicima koji su bili natašte dana je slana tekućina (oralno opterećenje solju), nakon čega su randomizirani za placebo $(500 \mathrm{~mL} 0.9 \%$ fiziološke otopine) ili infuziju GLP-1 (1.5 pmol/ $\mathrm{kg} / \mathrm{min})$ tijekom $3 \mathrm{sata}$. Na kraju infuzije ispitanicama su predočene slike hrane koje predstavljaju 5 osnovnih okusa pa su birali okus kojem su najviše skloni. Nakon 7 dana postupak se ponovio; onima kojima je prvi puta dan placebo primijenjen je GLP-1, a onima koji su prvi put dobili GLP-1 primijenjen je placebo. Promjena sklonosti određenom okusu nakon infuzije GLP-1, no ne i nakon placeba, smatrala se pozitivnim odgovorom, a negativan je bila nepromijenjena sklonost okusu. Analizirajući ispitanike prema spolu nađeno je da žene imaju veću vjerojatnost promjene sklonosti okusa nakon GLP-1 nego muškarci, što je bilo statistički značajno. Navedeno opažanje promjeni okusa nakon infuzije GLP-1 u ispitanica može se objasniti učinkom estrogena na gubitak tjelesne mase koji se objašnjava receptorski posredovnim prijenosom.

Ključne riječi: Glukagonu sličan peptid 1; Okus; Hrana, preferencije; Ukriženo istraživanje; Dvostruko-slijepa metoda 